University of New Mexico

UNM Digital Repository

History Faculty Publications

Scholarly Communication - Departments

2005

\title{
Modern German Universities and their Historians since the Fall of the Wall
}

Charles E. McClelland

University of New Mexico, cemcc@unm.edu

Follow this and additional works at: https://digitalrepository.unm.edu/hist_fsp

Part of the History Commons

\section{Recommended Citation}

McClelland, Charles E.. "Modern German Universities and their Historians since the Fall of the Wall." Journal of Modern History, 77 (2005), 138-59. (2005). https://digitalrepository.unm.edu/hist_fsp/7

This Article is brought to you for free and open access by the Scholarly Communication - Departments at UNM Digital Repository. It has been accepted for inclusion in History Faculty Publications by an authorized administrator of UNM Digital Repository. For more information, please contact amywinter@unm.edu. 
Modern German Universities and their Historians since the Fall of the Wall*

by

Charles E. McClelland

[Draft of a review article later published in Journal of Modern History, 77 (2005), 138-

59. For works reviewed see APPENDIX below.]

Over three decades ago the attention of the scholarly world was turned to its own doorstep by the insistent clamor of student protest as well as less raucous but more persistent calls for reform and justification of universities. The "68ers" are now the dominant adult generation, for whom a retrospective on the achievements and failures of the revolutionary spirit of yesteryear may be on the agenda. One can debate how deep or serious the impact of all that turmoil might have been on American higher education, despite many changes still with us today. The German higher education landscape, however, was clearly changed in fundamental ways.

At the end of the 1960s, launching major scholarly studies of the "sociology of education" - including by such centers of historical research as Princeton's Shelby Cullom David Center - seemed obvious and logical, as well as suddenly pressing. As its first director Lawrence Stone wrote, "The university, like the family and the church, is one of the most poorly integrated of institutions, and again and again it has been obstinately resistant to changes which were clearly demanded by changing conditions 
around it. And yet, in the long run, no institution can survive indefinitely in glorious isolation, and the interaction between the university's own built-in conservatism and the pressures upon it to adapt to new external conditions is one of the most potentially illuminating, but most practically obscure, aspects of the process of historical change."i American protesters and reformers were, to be sure, confronting a high education landscape that had already changed significantly since World War II, via opening and expanding recruitment (GI Bill, government and private scholarship and research aid) down to the interlinking of Cold War "defense" projects with research funding. Postwar Germany's higher education system remained, by contrast, little changed in structure and population. Indeed, government efforts before 1968 to open it up a bit and make it more directly serviceable to a modern economy showed that the dynamics of reform came chiefly from outside. A historical "sociology of education" of the sort promoted by Stone struck many German professors as suspect, even dangerous and heretical. Faculties still containing many professors with compromised or suspected "brown" pasts in West Germany were able to invoke all sorts of reasons for denouncing historical study of their own enterprises (especially recently) using the methods of the "sociology of knowledge," the history of science, or, for that matter, any kind of critical or even archival approach. Even in a "reform university" such as the new (1948) Free University of Berlin, located in the American sector of the city and initially funded by Ford grants, many professors were incensed and fearful over an innovation already common in American universities, namely student course evaluations. While Cold War rhetoric could be invoked to denounce such "subversive" attacks on the dignity and authority of universities as "Marxist" (one recalls the Bund Freiheit der Wissenschaft), the self-styled creators of 
"real-existing socialism" across the Wall hardly encouraged application of such critiques to their own educational system, either.

So much fear and repression, so many tacit taboos and open prohibitions hardly stimulated critical histories of higher education and its institutions. The genre "university history," for example, typically continued the hoary tradition of "jubilee publications," sometimes interspersed after the 1960s with collective volumes meant to explore at least the surface of events during the twelve years of the Hitler dictatorship. Jubiläums-

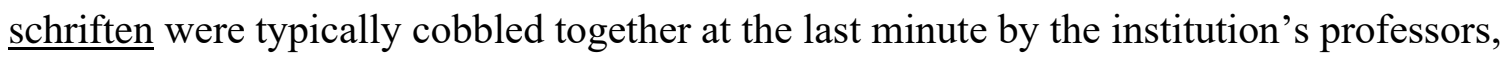
with much attention to the internal development of seminars and institutes (about which the authors usually knew a lot) and much less to the wider setting of the whole university in its social, political, and economic relationships. Not seldom, such "history projects" were considered too important to entrust to professional historians. Although I know of no cases in Germany comparable to the suppression of a commissioned scholarly "jubilee history" because it turned out not to be a coffee-table picture book as expected by the administration of an American state university not too many years ago, the temptation to please (or indeed impress) boosters, graduates, legislators, and other benefactors is not absent in Germany, either. Universities have had many open critics and enemies since the late 1960s, and the knee-jerk instinct of those who feel embattled inside the ivory tower to use anniversaries as an occasion for positive and reinforcing rituals of image-polishing is understandable, even if reprehensible. Lacking alumni associations, booster clubs, and professional athletic teams to enlist public sympathy and support, they have been tempted to rely on flattering self-portraiture. 
The collapse of the German Democratic Republic (GDR) in 1989 and the subsequent opening of its archives gave a new impetus to historical research using western standards, including about the educational system regarded by the regime itself as pivotally vital. One of the keys to successful integration of East Germany into the Federal Republic, almost everybody recognized, had to be the educational system, which had been most profoundly reshaped by the SED on the tertiary level. ${ }^{\text {ii }}$ The wholesale Abwicklung ("winding up") of university institutes and professors, especially in more politically-sensitive disciplines, seemed to open an opportunity for a new beginning of reform that had become bogged down in West Germany in preceding decades. Much of the new scholarship recognized the socio-political embeddedness of educational history and reflected a felt need to understand how universities change, as a part of a continuing field of discourse embracing also educational, cultural, and research policy.

Perhaps coincidentally, the massive transfer of German resources from west to east (not only to the "new German Länder" but, as aid and investment, the former Soviet bloc as well) since 1989 has led to growing complaints about reallocation of funding for “cultural” (including educational) investment. Universities and research institutions generally face ever-tighter budgets and are asked to do more with less. The fat years of the Wirtschaftswunder are over. Achieving excellence on a shoestring was, however, one of the noted accomplishments of German universities and science throughout most of the last two centuries. A raised tacit question about how this was accomplished may be contributing to heightened interest in scholarly studies that a few decades ago might have been deprecated as mildly "antiquarian" or parochial. If one assumes, as most German 
leaders now do, that the country is lagging in preparation for the IT world of the future, then its higher-education system must be reexamined.

Additionally, during the past generation Germany's anchoring in a wider European and global framework has provoked discussion about cosmopolitan vs. merely regional or national settings for universities. With its highly export-oriented economy, need to keep and even improve its standing among the elite of scientific and technological countries, its political, diplomatic, and security enmeshment with the EU, NATO, UN, and its backyard in Eastern Europe and the Middle East, the Federal Republic of today counts on its role in the internationalization of higher education in teaching and research. Germany today may be a net importer of educational trends, but it has a long tradition (even if somewhat exaggerated) of exporting them, too, including the "Humboldt model."

All these changed perspectives have created a need to revisit the history of higher education beyond the level of the Jubiläumsschrift. And were this not enough motive, the continuing detailed confrontation with the Nazi past has been facilitated by several factors, including continuing public interest in such questions, the easier availability of historical records, and generational change. The ensuing temptation to lavish more time on the crisis-laden twentieth century and especially the "brown years" is often evident in the space devoted to them even in jubilee volumes meant to cover centuries. ${ }^{\text {iii }}$

I. 
In contrast to other European and North American university traditions, the historiography of universities in modern Germany has strongly emphasized the professorate. This was understandable in a "system" emerging in the nineteenth century that linked the enterprises of "teaching" and "research." Variants such as the Oxbridge and French systems consciously placed most basic research (and consequently scientific and scholarly fame) elsewhere; from the Humboldt era at the latest, Wissenschaft was woven into the rationale of German universities. The full professor (Ordinarius), especially if also the head of a disciplinary fiefdom (Institut or Seminar), often counted among the elite of original scholars and scientists of Central Europe and sometimes the world. True, less the love of pure learning than the need for professional training attracted the vast majority of students. Those who sought to become professors had increasingly to demonstrate more than mere competence, however, and the high standards ratcheted up German universities' world standing at least until World War I, and even some little time beyond that.

How the best minds of several generations were attracted into university teaching, especially considering the comparatively low prestige of this occupation before 1800 , is a question that has often been asked, classically for example by Joseph Ben-David and many others since. Martin Schmeiser, in Akademischer Hasard, ventures a complex sociological explanation. Departing from Max Weber's famous lecture on “Wissenschaft als Beruf, ${ }^{\text {'iv }}$ Schmeiser casts doubt on the notion that higher educational professorships belonged to the "learned" professions. Like such "charismatic" occupations as artist and politician, that of professor lacked a dependable career ladder and was "hazardous." Focusing on the unique German institution of the private docent, originally the recruiting 
pool and ultimately the alternative reserve army for keeping down the cost of hiring expensive full, “ordinary”professors, Schmeiser develops the argument that the Privatdozentur in the end caused the decline of the German "research university." "Educational virtuosi and [financially] independent people without an occupation were those to whom the private docentship offered, along the path of internal and external selection, optimal chances to become the dominant groups. If the Privatdozentur conceded a right of preemption for the office of professor to these two milieus, then it is safe to assume that the institutionalization of the Privatdozentur at the beginning of the nineteenth century is connected causally to German science's loss of world standing at the beginning of the twentieth.” (Schmeiser, pp. 324-5)

Reduced to its simplest form, Schmeiser's argument claims that the financial means and family backing of the better-heeled aspirants to an academic career enabled them to survive the selection process with better chances and more options - even down to the level of being able to choose more prestigious and lucrative medical specialization as opposed to a career in basic medical science.

Among the many strengths of Schmeiser's work, appendices offer a wealth of statistical information as well as an enlightening methodological excursion about academic biography and prosopography. Here we see clear traces (evident in other recent literature as well) of the reception of Pierre Bourdieu in Germany. The evidence supports, if sometimes only by tendency, the author's conclusions that higher social origins and financial independence increasingly favored the chances of career success of the professors studied. In other words, “...it was Rentiers who, in the time of expansion of qualification requirements, as expressed in the rising age of first professorial 
appointment, increasingly determined the social composition of the professorate." (Schmeiser, p. 324) The author no doubt exaggerates in using the term "plutocratization" of the professorial career, but his samples did show an increasing tendency of recruitment from the Besitzbürgertum in addition to the previously predominant Bildungsbürgertum.

A few corrective comments might be raised, though. The general student population at German universities followed a comparable curve of rising recruitment from the burgeoning commercial class from the time of the founding of the German Empire until the eve of World War I. Furthermore, the power of Schmeiser's generalizations is diminished somewhat by his selection of representative samples only from the legal and medical professorate (and only 25 cases from each discipline). Law studies traditionally attracted a higher proportion of socially and financially prominent students and served more as a gateway to the civil service than (by almost anybody's expectation) a bastion of international scholarship. Hence the suggestion that a "plutocratization" of the law faculties might have led to the loss of Germany's scientific "world position" is dubious on several counts. Medical faculties, in contrast, were highly favored in the late nineteenth century by sons of upwardly-mobile new-money families (including unconverted Jewish ones, who had good reason to doubt the chances of their offspring in the relatively hostile preserve of the Reich and federal states' civil services but saw good career prospects in the private practice of medicine). The medical faculties of Imperial Germany did indeed produce world-class research and discovery. But did that cease after 1900? And if so, post hoc propter hoc?

The solid statistical work behind Schmeiser's book makes it a considerable advance on the previous "standard" about the Privatdozentur. ${ }^{v}$ Extracts of professorial 
life stories as well as the construction of such "habitus" categories as "the ideal rich heir" or "the promising (sons of pastors and teachers)" work to provoke thought and add texture to massive statistics. The work of Baumgarten and others should of course be consulted as a corrective to the viewpoint imposed by Schmeiser's chosen parameters of research.

Schmeiser takes very drastically and seriously contemporary complaints in the last years of the Empire about the "decline of the German university." (Schmeiser, p. 26) Much of that complaint, however, concerned other issues than the decline of "science". From the perspective of humanist professors, Humboldtian concepts of Wissenschaft were yielding to what Adolf von Harnack called "a big factory" model of universities as well as "big science" carried on outside the walls of the ivory tower.

II.

German Wissenschaft, whether based in or outside universities, certainly was undergoing at least one kind of "crisis" by the turn of the twentieth century. University research facilities, staff, and budgets could not keep pace with the burgeoning demand for scientific research, and in Germany (as elsewhere) new solutions for promoting it had to be sought. Already before World War I, the Kaiser Wilhelm Society was set up to coordinate funding of research in several natural science fields. During and after the 
catastrophic war and subsequent peace settlement of 1914-19, German science suffered severe funding shortages (along with many other sectors of public life): at the end of the war, even before the Great Inflation culminating in 1923, extant research budgets had shrunk to only one-seventh of their 1913 level. (Hammerstein, p. 32.) Heavy reparations to the Allies and their attempts to excommunicate German scientists from renewed international contacts not only fed resentments and patriotic acceptance of the "stab-inthe-back legend" among German faculties; they also underlined the pressing need for promotion of science on a national level. Yet education, science, and "culture" in general were the responsibility of the financially-strapped states under Germany's federal system.

The creation of the Notgemeinschaft der deutschen Wissenschaft in 1920 and its evolution into the Deutsche Forschungsgemeinschaft (German Research Foundation, DFG) by 1929 may at first glance appear out of place in a review of university history. But from its inception until today, the DFG has played a major and interactive role with the research functions of higher educational institutions. Many of the smaller states could not keep pace with increasing demands for basic research at their "dual purpose" higher educational institutions (including technical colleges), and the DFG has attempted to respond to that need for almost a century. Both its leadership (augmented by distinguished members of the business and political communities) and most of its beneficiaries were German professors, and increasingly in almost all fields of scholarly investigation, not just the natural sciences. Its aid and grants effectively recognized areas of research needing concentrated encouragement. In this regard the DFG and its predecessors continued a policy of the influential Prussian Ministerialrat for universities in the Kultusministerium, Friedrich Althoff, in the decades before World War I. Althoff 
had attempted to build up the critical mass of researchers and facilities in disciplines or subdisciplines at individual Prussian higher-educational institutions. In a country lacking the tradition of wealthy private foundations, such as the United States developed by the early twentieth century just in time for "big science," the DFG has taken on some of their roles. One of the most important of those is to channel research funding from source to recipient in a way consistent with objective perceived needs of the broader scientific and scholarly community. Autonomy, disinterestedness, and probity are thus essential to the very core value of such a sponsoring organization.

How deeply were those properties compromised by the Third Reich? This central question, hovering over all scientific and scholarly institutions, is also addressed by Hammerstein's book (as well as by a recently-published dissertation). ${ }^{\text {vi }}$ The answer to this question comes down to how it is posed.

For Hammerstein, the question is one of policy, which the Nazi regime was unable to formulate or carry out in a consistent and clear manner, regardless of the willing, unwilling, or indifferent attitudes of scholars and scientists (largely working at universities) sponsored by the DFG. As with most other autonomous organizations, from professional associations to art leagues, Gleichschaltung (“co-ordination") with Nazi wishes and policies was inevitable; the subtle question remains, did voluntary selfsterilization prevent the birth of more opposition than its alternative, forced from outside by the NSDAP? Formally, as well as in many practical ways, Hitler Germany was a "leader state" and could and did impose its will on scientists if they could not be coopted. If it did not succeed fully in doing so, or if it did achieve a measure of willing cooperation, the causes were undoubtedly more complex than simple black-and-white 
"collaboration or resistance". As critics of this and other studies have pointed out, looking at the wider picture of economic planning by state, party, the military, and industry - the German equivalent of what President Eisenhower later dubbed the "military-industrial-congressional complex"vii - yields a different evaluation than looking merely at the personnel and policies of the DFG. (The succession of presidents of the DFG in the interwar years says volumes about its reorientation: from republican-Prussian Culture Minister Friedrich Schmitt-Ott through the arch-proponent of "German physics" Johannes Stark, who, like so many early allies of the Nazis, still had to be dumped after the consolidation of power for the young Himmler protégé and undistinguished military research chemist Rudolf Mentzel.) But as Hammerstein points out, "Even opponents of the regime tried, in the interest of their people, to perform solid and responsible work, since hardly anybody wanted the defeat of their own country and the victory of Germany's enemies." (Hammerstein, p. 543) Thus by the time the regime began to wake up to the possibility of defeat, from 1942 on, its further concentration on science useful for the war effort (a major rationale anyway since the intrusion of Goering's Four Year Plan into the activities of the DFG via the Reichsforschungsrat or National Research Council from 1937) did not mean shutting down "normal science." For "by 1943 all projects were considered vital for the war effort merely by the fact that researchers involved in them had not been drafted or reassigned." (Ibid.) In Hammerstein's conclusion, Nazi science policy, such as it was, ran aground on the banks of stubbornlydefended (because previously effective) traditions of research autonomy. Clinging to that "world of its own" may have blinded many scientists to the questionable and even 
criminal uses to which much German research was being put and that the DFG had become merely a "clearing house for the Reichserziehungsministerium."

Such conclusions will not satisfy those who pose the question differently, from the perspective of intentions not results. The suspicion that much larger numbers of scientists - and not just mediocre or opportunistic ones - were committed to Nazi goals and attitudes will not be dispelled by such conclusions. The trend during the (very) "short thousand-year Reich" rolled clearly in the direction of organizing and mobilizing everything from the top down. In a what-if scenario, a continuation of the Hitler regime by any plausible means would probably have meant an eventual elimination of all loci that could later be called "autonomous." No doubt the majority of scholars and scientists surviving actively into early 1940s Germany would have been able to adapt to a victorious and permanent Führerstaat, just as Wernher von Braun and many others adapted smoothly to "democracy" in defeat. Historians expecting widespread suicidal heroism in resistance, or even vocal opposition in the name of transcendent scientific, scholarly, or ethical values, will usually be disappointed. Historians looking for complexity, compromise, continuities, and the survival of scientific institutions and agendas even in the face of avowed contempt and loathing by their political masters, will find these features, too. Had universities not been able to adapt to new socioeconomic and political conditions since the middle ages, there would after all be no recent history of them to write.

III. 
The study of "universities under fascism" (and to a varying degree under other kinds of dictatorships) presents special problems and challenges. The especially virulent, violent, racist, and culturally reactionary fascism-variant National Socialism has from its inception struck observers as a particularly dark stain against the relatively bright oasis of German Bildung and Wissenschaft, themselves set off against the gray background of political and economic miseries and failures of the past century. It is perhaps this dramatic chiaroscuro that provokes again and again the question "how was it possible?" After all, educational and research institutions hastening to align themselves "in spirit" with the larger goals of fascist and other dictatorial regimes elsewhere in Europe do not surprise historians in other countries. Why the surprise about Germany? Were its standards so much higher, its professors, researchers, and students such cultural

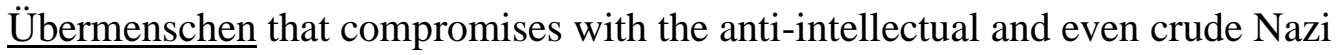
movement seem more like a betrayal of professional and moral values than a tactic of survival? Of course this dramatic scene becomes even more charged by the attempts to those very same Germans after 1945 to deny or excuse collaboration or justify nonresistance.

Denial became more necessary in German university settings for a number of special reasons. Of all the Axis powers Germany was unquestionably guilty of the most heinous crimes against humanity and peace, abetted in both by universities. It was also the last European fascist belligerent to surrender, holding out bitterly to the end with blind obedience to Hitler. The shameful murder of millions of civilians had been carried 
out in the name of "German racial hygiene" based on principles of German "science" (even if these were, incidentally, much more widely accepted as respectable in the world community, especially the USA, before 1945 than it is today comfortable for many to acknowledge). As Tom Lehrer's eponymous song later parodied, “The widows and orphans of old London town/Owe their large pensions to Werner von Braun" and German rocket science. Given the special personal hatred Hitler expressed for professors and academic life generally, those who had survived in his universities might be suspected of being especially compromised.

The Allied occupation of Germany recognized this special culpability of German elites by such extraordinary measures as "denazification" with its attendant threat of severe penalties for proven active and willing collaboration with the defeated regime. ${ }^{\text {viii }}$ The cottage industry of denial that resulted, the scramble for Persilscheine or official attestations of "cleanliness", naturally involved the academic world, too, along with the rest of the state civil service structure. Finally, Germany quickly became the front line of the escalating Cold War, and a sepia wash in one's background became less objectionable to Western Allies and West German political leaders than the reddish hue of "the other subverters of Weimar democracy."

For all these reasons a complete settlement of accounts, a satisfying Vergangenheitsbewältigung, did not happen in most West German universities. The situation in what became the GDR had its parallels: "bourgeois" professors were considered suspect, even if they had actually been persecuted by the Hitler regime. Thanks to the quirks of Stalinism, though, not even survival of Nazi persecution and loyalty to the KPD or SED guaranteed a smooth career path in the decade after the war. 
Nor were East German universities, despite official "antifascist" rhetoric, able to function without reemploying dubiously "brown" professors, as the relevant works under review here clearly show. Many of the current crop of university histories set out to settle these accounts, or at least to avoid the appearance of accepting the "myths" propagated by many of the denizens of German universities between 1933 and the recent past, whether by denying the extent of their collaboration or having others paint a picture of "helpless anti-fascism."

Some of these works focus almost exclusively on this reckoning, limiting the questions to be posed to the degree of involvement by university members in Nazi organizations and social strata outside academe, the impact of Nazi policies on the shape, purpose, recruitment, and "modernization" of universities as well as the professional labor market, and similar topics. Such, for example, is the catalog presented by Peter Chroust (I, p. 28). Personnel continuities before and after 1945 aside, can one maintain that there was a continuity of the "German spirit," a mix of "völkisch nationalism, antiSemitism, and biological and cultural racism ... [rejecting] the concept of 'value-free' scholarship,” as Steven Remy declares? (Remy, pp. 6-7) Or, put at its most straightforward, as by the Anette-Chr. Nagel, these studies wish to answer questions about "the degree of saturation of the ... university with National Socialist ideology." (Nagel, p. 7), without either skirting issues or continuing denial, the typical faults of previous "jubilee literature," or on the other hand indulging in the often fragmentary, one-sided, and denunciatory faults of "counter-Festschrift" exposés meant as a corrective to a conspiracy of silence. The two books devoted all or in part to Jena and Halle in the Nazi period (Gottwald and Eberle) are more limited in their methodological ambitions: in 
Halle a social-history approach proved "impossible", and in the Jena volume, a "workshop" product of a conference, there are only essays on different aspects of the university's twentieth-century history, including 1933-45. The neglect of certain areas of historical research under the GDR still leaves traces in attempts to "catch up": studies devoted to universities located in the FRG have enjoyed relatively longer and greater freedom of research and material support.

How these five methodologically very different studies answer the questions they pose comes down in large part to a difference between intellectual and social history. Perhaps by happenstance, the three universities studied by Chroust, Nagel, and Remy lie within commuting distance of Frankfurt/M. and had much in common otherwise heavily Protestant traditions and student recruitment, small-town settings where gown was the town, middle to small size, and comparatively modest "ranking" in the constellation of German science and scholarship. Heidelberg was more distinguished by the liberal (i.e. tolerant and diverse) traditions fostered by the Baden government, a relatively cosmopolitan student body, and some outstanding intellectual achievements, for example in the social sciences.

All five books agree on the broad outlines of their story. The university faculties of the Weimar era were, with notable exceptions, still saturated with an arch-conservative political culture that detested or at best tolerated the Republic and hated Versailles. They were highly nationalistic and shared most of the common prejudices of the educated middle class of the time, including at least social antisemitism, monarchism, and (varying from individual to individual) others such as biological and social Darwinism, romantic messianism, cultural pessimism, and authoritarianism. There were of course numerous 
exceptions to this pattern, professors sympathetic to liberal, socialist, and even pacifist causes, but they were as much a minority as truly original thinkers. The political parties that came closest to representing the majority view of the professorate would have been the DNVP (Nationalists) or Stresemann's DVP (People's Party), also the Center for Catholic professors, but few even deigned to play an active role in "dirty" electoral politics. Rarely, in other words, did the (often remarkable) analytical skills of noted scholars and scientists alter or shake the more or less predictable prejudices they absorbed outside the sphere of Wissenschaft. ${ }^{\text {ix }}$

Nevertheless, despite proto-fascist proclivities among the professorate, it was students, rather than professors, who were the first to feel a strong attraction to the NSDAP, especially in provincial universities like Marburg and Giessen. (Indeed, Nazi student disruptions constituted a major weapon of intimidation used against the professorate before and after 1933.) Only the Nazi seizure of power truly opened the door to cooptation and cooperation by the professors with the regime, not that they would have had much choice had they resisted: the breaching of university autonomy, and the removal of anybody who resisted, was the first order of Hitler's educational policy. The first major impact of Gleichschaltung at all universities came through the Civil Service Law of April 1933, removing faculty members of "Jewish descent" (except for veterans and more senior civil servants) and of leftist, pacifist, liberal, or other politically oppositional reputation. When the opportunity presented itself, as with the lifting of the NSDAP's ban on new membership in 1937, many surviving professors joined or otherwise affiliated themselves with Party organizations. Nazi laws designed to reduce the bloated student populations of the Depression years (tuition-free college study being 
preferable to outright unemployment) similarly thinned out not only Jewish and politically objectionable students, but women as well.

Like so many of the other books from Germany discussed here, the Chroust and Nagel volumes rely on social-historical analysis. Remy inclines more to a kind of intellectual history, or what one might call a history of guilt by idea-association. In a well-written and well-researched monograph, he provides a good exemplary analysis of how a German university was both "Nazified" and "de-Nazified," raising disturbing questions about the incompleteness of the latter process. Although this story is hardly new, it is told here in a form readily accessible to readers unable to access comparable German-language publications. What makes this reviewer uncomfortable is the slipperiness of Remy's working definitions of "Nazi." Clearly he sympathizes with the radical judgment of one of the zealous young American Counter Intelligence Corps (CIC) officers assigned to Heidelberg, Daniel Penham (born 1914 as Siegfried Oppenheim and forced to flee Nazi persecution in 1933), that the entire faculty was "Nazified to the core." (Remy, p. 146) To agree with this conclusion, one would have to accept the widest possible definition of "Nazi", including attitudes shared with pre-1933 non- and even anti-Nazi political movements. One would have to take most signs of collaboration as active and willing, dismissing motives of perceived compulsion or "preventing worse" as retrospective camouflage. One would have to, like Penham, compulsively stay up nights reading everything all professors wrote and said over twelve years (an impossible task in the judgment of his superiors) for any hints of Nazi intellectual content, denying that any of it could be hypocritical lip-service at the time of writing. Given the parasitic and derivative nature of most Nazi "thinkers" and the heterogeneous sources of their 
"intellectual components," such a method can veer close to painting most of the Bildungsbürgertum brown and ending in such mirror-racist mental short-circuits as Goldhagen's. Is it helpful? Remy is of course much too careful and scrupulous to endorse fully the argument of Penham and the "vocal minority of CIC officers" who advocated passing all professors through the eye of a very narrow investigative needle before allowing them to teach again after 1945, even if that meant keeping German universities closed. Remy is undoubtedly right in decrying the resulting rehabilitation of such (as it later proved) deeply compromised professors as K. H. Bauer, the university rector at the end of the war.

That many Nazi party members and professors with suspect pasts crept back into the teaching ranks after 1945-6, which seems to fuel a certain outrage in Remy's book, is hardly a new revelation. As Eberle's work on Halle shows, even under Soviet Occupation Zone "de-Nazification" oversight, "victims" of earlier Nazi purges were denied restoration of their position or compensation just as deliberately as under American oversight at Heidelberg, while many "perpetrators" or at least beneficiaries of the Nazi university revolution were allowed to come back. (Eberle, p. 267) As Eberle also points out, the remaining faculty members at Halle after 1945 were just as likely to adjust to the new Communist overlords as they and their predecessors had to the Nazi regime (although many were able to move to West Germany before the construction of the Wall in 1961). Comparing all the works covering the Nazi as well as postwar Communist periods, one is struck as much by the survival techniques in a hostile environment as by the imputed moral cowardice or proven loud collaboration of professors with dictatorships. The constant threat of denunciations and agitation by Party-affiliated 
student groups or other agents, many self-interested, interference by local or national Party and government officials in university administration (pitting the "Führer-Rektor" against his own clientèle or other external "bosses"), the trend toward reducing university institutes to handmaidens of practical regime-favored or war-related research in both Nazi and Communist Germany, and even the fall of once-promising, ambitious Partyliners into the abyss of non-person status remind the reader of the crushing weight of totalitarian "town" bearing on a fragmented, divided, and relatively defenseless "gown." It is not difficult to see the rationale (while not overlooking the self-serving element in the rhetoric) of professors - even including Karl Jaspers in postwar Heidelberg -- who insisted on "restoring" the autonomy and authority of the "full professor university" (Ordinarienuniversität) after 1945 as more important than combing out all who were compromised by collaboration.

"Relativizing" the German historical experience in the twentieth century is of course perilous, since there are many who would prefer that Hitler Germany remain an incomparable standard of human depravity. Yet millions of European civilians were killed just as dead without the Holocaust, part of them by other agents and even enemies of the Nazis; and thousands of students and professors outside Hitler's Reich suffered fates comparable to their German colleagues. As the essays in the conference volume by Connelly and Grüttner agree, dictatorships from interwar fascist (Italian, German, and Spanish) to postwar East Central European (Russian, Polish, Czech, and Hungarian) and Chinese ones applied comparable demands for conformity (including personnel purges, ideological indoctrination, as well as research and teaching programs aimed at strengthening the economic and military viability of the regime) and curtailment of self- 
governing autonomy. By "making themselves useful" to their new masters, the remaining professors and students were often then able to save their institutions, their status privileges, and some shreds of independence. Too high a price to pay, or, as Grüttner tends to argue, an understandable "defense of professional interests"? (Grüttner, p. 272)

IV.

The fate of the postwar university system is well documented in three further works of recent vintage, those of Jessen and Kowalczuk for East Germany and of George Turner on the Federal Republic. It is surprising how many parallels emerge between developments in "capitalist" and "socialist" higher educational policy when viewed from a high enough level of abstraction. Jessen concentrates on the East German professorate and does not examine institutional structures, students, professional graduates, and other matters in detail. Kowalczuk, while covering an even shorter period of GDR history than Jessen, looks at the university system more as a factory for producing a new intelligentsia and thus concentrates on elements treated as secondary by Jessen. The latter concludes that the SED regime did bring about a fundamental change in the professorate and structure of the universities: "Neither the terror and 'co-ordination' under National Socialism nor the West German student movement and the university reforms following it changed the profession, structure and milieu of the academic elite in Germany as fundamentally as the totalitarian social experiment of the SED.” (Kowalczuk, p. 429) Kowalczuk agrees that even by 1961 the university system had been "largely 
refunctionalized as a socialist institution," but he also emphasizes the relative failure of the SED's goal of creating a new party-sustaining Intelligenz.

George Turner, a law professor rather than a historian, is an experienced participant in the reforms of the higher education system of the FRG. He was head of the West German Rectors' Conference (1979 - 1983) and for three years thereafter Senator (state minister) of Science and Research in Berlin. He leaves little doubt that, in his view, the Federal Republic's university landscape was largely refunctionalized as an appendage of the state bureaucracy. "The old university as European educational institution got left behind and broke in the concentrated grasp of revolutionaries [students] and bureaucrats." (Turner, p. 19) The "helplessness" of the assaulted Ordinarien in trying to cling to their former power cannot but remind one of similar attempts by their colleagues or predecessors in Nazi Germany or the GDR, although Turner does not dwell on cases (undoubtedly legion) where some of the old autonomy was tacitly salvaged by compromise, collaboration, or quiet subversion of the reformers' intentions. As under Hitler and Ulbricht, "Economic growth was understood to be the condition and result of cultural [and educational] policy.” (Turner, p. 21) But the author emphasizes that everything is complicated, and the course of thirty years of reforms can best be described as "meandering” or "zig-zag”. Certainly one cannot speak any longer of "the” German university (Turner, p. 272) Ironically the attempt to overhaul the traditional (dare one still say Humboldtian?) university to make it more "democratic" as well as to make the German society and economy more verwissenschaftlicht (with higher education playing the spark-plug to the Information Age) had sometimes paradoxical results. Turner points to a shortage of graduates yielding to a vast surplus; complication instead of streamlining 
of study programs; trends to top-down management instead of bottom-up participation; more influence of business and industry than before; introduction of student tuition fees and ongoing fights over adequate scholarship aid, instead of guaranteed free access to all qualified to study; and many others (Turner, p. 273)

Turner's book is brief and pithy, providing a valuable insider's view of the immensely complicated and confusing Thirty Years' War over Bildungsreform in West Germany (and since 1989 by extension into the former GDR as well). And it does remind the reader of all these other books as well that there are broader issues about the relationship of state, society, and university than sniffing out brown pasts or "class enemies," compromises with dominant ideologies and paymasters, or the "perversion" of "pure" research and disinterested scholarship. So many of the broader trends described for postwar Germany - East as well as West -- can also be found in most developed countries to some degree.

\section{V.}

Naming and then exposing Remy's specific "Heidelberg myth" (a once pluralistic intellectual bastion suffering a Nazi purge only to return to postwar purity) might seem novel to Harvard University Press, but for decades there has been little doubt in Germany about persistent myths surrounding the "Nazification and de-Nazification" of the university system. There have been other oft-invoked myths, as well. The tools of social history and critical analysis have necessarily faced these myths, some of which are generic and international (the altruistic or at least harmless-distracted "ivory tower") and others unique to Germany. Among the latter, the "Humboldt myth" is still invoked to 
summarize the best aspirations of German Wissenschaft. The heart of that myth lies in the notion that the attachment to open-ended scholarly investigation, as exemplified by the cosmopolitan brothers Alexander and Wilhelm von Humboldt in the first half of the nineteenth century, was successfully and permanently infused into the university system. ${ }^{\mathrm{X}}$ The kernel of truth in that notion is that universities did (following the examples of Göttingen and the new foundation of Berlin after 1810) gradually add a "research imperative" to their traditional teaching role. (By the eve of World War I, the explosion of research needs, e.g. in natural sciences and technology that could not adequately be met by the education-oriented university structure led to crises and extra-university solutions.) The idealization lies in the idea that universities were thereby transformed into ethereal refuges where professors and students "lived for science," enjoying "freedom of teaching and study" (including students' freedom from most mandatory instructional fees), contrasted to the mucky and compromise-filled world of business, politics, and war. The advent of a social-historical approach to their past has revealed in ways previously little used how the "everyday" university worked and who its members were (as opposed to what they said and perhaps hoped about themselves).

Two of the works under review here address the "Humboldt myth" in its guise as a German export. The impact of the nineteenth-century German university "model" abroad (for example on Japan and the USA) has long been taken for granted in a vague way. But how, precisely, was it perceived and adapted abroad? A "cost-benefit analysis" made the "model" interesting enough, since it eliminated a certain amount of duplication between modernizing higher-educational institutions and such purely research-oriented organizations as academies of science. The conference volume Humboldt International, 
edited by Schwinges, looks first at the export of the model from Prussia to other German states, then at international diffusion in Europe, North America, and Asia. Schalenberg's monograph thoroughly investigates the "reform discourses" about French and British higher education with reference to the "Humboldtian" model.

Schalenberg's book is made more manageable in some ways and less useful in others by its narrow focus on the period down to 1870 and to (chiefly) Paris and Oxford as landscapes of higher education. It was arguably after 1860 that the "German university model" began to have the most serious effects on actual reforms abroad. Schalenberg thus concentrates on the "reform discourse" at and about the centralized post-Napoleonic system in France and the unreformed, still largely medieval institutions in Britain from which the young Gibbon had fled in horror decades before. The Université Impériale of 1808, with its division between the "rationalistically-conceived training machine" of $\underline{\text { lycées and higher facultés on one side and research institutions of the Institut de France }}$ on the other, carried on with largely unbroken traditions down to at least 1870, with only the addition of the École Pratique des Hautes Études (1868) and a few stirrings such as expanded library resources at other Grandes Écoles to break continuity by encouraging university-level "research". Although the Oxford proponents of reform tended to look favorably on German universities (and conservatives with horror), the issues culminating in the recommendations and incomplete implementation of the Royal Commission (185054) had as much to do with accepting or rejecting the very idea of modern state intervention (common to both German and French systems) as the details of the "German model" (the French one being acceptable to virtually nobody). 
In the end it is not the reality of the German "model" (or reliable descriptions of it from abroad) that forms the heart of Schalenberg's theme, but rather the way in which the intentions and interests of British and French protagonists and antagonists used alleged parts of that "model" (also negative ones) in their discourse about reform. The way some of the topoi were presented - from the role of the state, the meaning of "freedom" (of study, teaching, and research), religious tolerance, scientific innovation and objectivity to such fears as heresy and speculative intellectual subversion - rather than their accuracy constitutes the central theme. The idea of "freedom of research and teaching" as proclaimed by Humboldt made many academics nervous, for it could undermine authority and lead away from solid practical educational goals. As Walter Bagehot (quoted in his reaction to the 1852 Royal Commission for Oxford Report) harrumphed, referring to alleged German metaphysical proclivities, "We are not Germans, who care for what is not." (Schalenberg, p. 355)

Similarly the conference volume edited by Schwinges regards the "model" as an ideal type, a construction after the fact. Neither in Germany nor abroad did reality merge with the ideal. The well-known components of that construction - such as the "research imperative," learning through research, freedom of teaching and research, the unity of scholarly knowledge - could also be debated and introduced without the invocation of Wilhelm von Humboldt's name, since his memo of 1808-10, $\underline{\text { Ueber die innere und }}$ äussere Organisation, was only rediscovered, published, and discussed widely in Berlin itself during the run-up to the university's centennial celebrations in 1910.( Schwinges, p. 9) Wilhelm von Humboldt himself, as Schalenberg (in his contribution to the Schwinges volume) reminds us, demonstrated only "flagrant disinterest" in Oxbridge during his brief 
stint as Prussian ambassador to the Court of St. James in 1817/18. (Schwinges, p. 232)

During his earlier multi-year visit to Paris in the 1790s, city whose cultural eminence he missed when forced again to live in Berlin, he may have learned skepticism about the "scientific cadet schools" resulting from the revolution, but Walter Ruegg found slight if not insignificant impact of the "model" on France in the nineteenth century. (Schwinges, pp. 250-1)

Not only did foreign higher educational systems (discussed here are Hungary, the Netherlands, France, Britain, Norway, the USA, Japan, and China) but also Berlin's rivals in Germany itself "adopted" only bits and pieces of the "Humboldt model" including the University of Berlin itself, in its early days, at least. As Rüdiger vom Bruch concludes: "One cannot speak of the founding of Berlin as a blueprint for scientificrational organization shaped to the lifestyle and political and social engineering of an industrial-society type that set institutional standards as a model of Wissenschaft in both the national cultural sphere as well as internationally.” (Schwinges, p. 73)

Or as Sylvia Paletschek's chapter here agrees, "The neohumanist university idea, postulated as timeless, served as a projection screen for discussions about universities taking place at different times, and could legitimate the status quo as well as reforms." (Schwinges, p. 103)

VI.

Scholars have long accepted as a corollary of the "Humboldt myth" the predominance of the new Prussian university in Berlin originating under the brief 
ministerial influence of Wilhelm von Humboldt (and renamed for him and his brother Alexander in 1949). Nobody seriously disputes the eminence of Berlin, which considering the size of its student body, faculty, research facilities, and financing would have had to suffer extraordinarily incompetent leadership not to place in the top three German universities throughout the period 1830-1950, at least. Although German academics have recently begun - under the influence of American obsessions about such issues - to ask how individual universities "rank" in some sort of prestige scale, the question can hardly be answered using American measurements (such as faculty publications, frequency of their citation by others, or size of outside funding), which are difficult to apply to the German system. One way to establish such a scale historically, however, would be to measure universities' attractiveness to career-mobile professors, as well as students, testing the rule of thumb that Berlin became (and until the Cold War remained) the pinnacle of professorial and student mobility. To "finish" one's career or studies there, so the clichés went, was to achieve ultimate success (at least from the viewpoint of Prussian academia).

Marita Baumgarten's scrupulously researched volume attempts to track this kind of movement among universities, although it limits its focus to the recruitment for regular professorial chairs in the philosophical faculties chiefly (but not exclusively) of the universities of Giessen, Kiel, Heidelberg, Göttingen, Munich, and Berlin from 1815 to 1914. In tracking the creation and filling of chairs, it shows the transition from the "encyclopedic savant" at inbred and largely family-connected faculties to the "specialized scientist and researcher" at achievement-oriented ones, and how arrival at the latter point placed the schools on a ranking scale. (Baumgarten, p. 267) To be sure, the philosophical 
faculties were the last among theology, law, and medicine (in that order) to go over to the new criteria for "calling" professors, but within them the natural scientists were the most liberated from family, local, or regional network considerations. (This did not prevent the rise of new generations of blood- and marriage-related "scholarly dynasties", one of the concepts added by Peter Moraw, but their members also had to meet meritocratic standards and were spread around the nearly two-dozen universities in what became the German Empire.) Perhaps not surprisingly, the larger universities were in a better position to evolve professionalized recruitment procedures earlier, but Berlin was not alone in this. Confessional (i.e. Catholic or Protestant - unconverted Jews were still largely kept out of professorships until after 1918), ideological, and political considerations still played a role in the selection process, although more for humanities professors than those in the natural sciences. Based on her mobility studies, Baumgarten ranks the prestige of the universities as follows: 1-3 Berlin, Munich, Leipzig (institutions at the "top of the career ladder", not coincidentally those with the largest enrollments), followed closely by Bonn and Heidelberg; the five schools of "upward mobility" Göttingen, Halle, Strasbourg, Tübingen, and Würzburg; the five "way stations" of Breslau, Freiburg, Marburg, Königsberg, and Jena; and the five "starter universities" of Kiel, Giessen, Erlangen, Greisfwald, and the "caboose” Rostock. (Baumgarten, pp. 2713)

Much of the published work on German university history since the fall of the Wall reflects an interest in "catch-up" (e. g., posing "western" questions to "eastern" universities) or "catch-em" (e. g., posing hard questions about the "undigested" Nazi or SED pasts). But what of the increasingly unfashionable tradition of studying a past more 
remote than one's own lifetime? Although in a minority, the works of Paletschek, Willett, and Müller (like that of Baumgarten) concentrate on pre-Nazi developments and (unlike that of Baumgarten) on a single institution. Die Universität Jena, however, reaches beyond academic walls to consider interactions with local and regional culture (with the “classical Weimar" of State Minister Goethe and Professor Schiller just down the road) as well as with the educational reform ferment of the age in all of Germany. The three editors and nine other participants in a conference sponsored by the SFB (Special Research Project) 482 of the DFG proceed to discuss Jena's place in the "reform path" between Göttingen and Berlin, between the "tradition" of ossified corporatism and the cultural dynamism around the court at Weimar, and interacting with extra-institutional cultural forces. As such it provides illuminating snapshot of two landscapes normally not juxtaposed by literary and historical scholars, where the intellectual Zeitgeist and pedantic isolation of university faculties begin to merge somewhat. It does not, however, claim to be a survey of the university as a whole, even for the brief time-frame it has chosen.

Much more ambitious is Paletschek's analysis of the University of Tübingen during the critical decades when it changed from a "classical" to a "research" institution, 1870-1930. Her findings are generally consistent with those of other works reviewed here, but with some additional intriguing insights and emphases. Tübingen was geographically (as well as by mentality) about as far as a German university could get from "Humboldtian" Berlin, although many of the national trends applied there (with some lag) as well. While she agrees with Baumgarten's assessment of Tübingen as an institution providing "upward mobility" for talented faculty (Paletschek, p. 329), she is 
refreshingly pragmatic about the reasons for the university's "ranking": it increased the size of its student body. Size rather than intangible prestige mattered and attracted better faculty members, because a large part of their income derived from the private lecture fees paid by students in addition to the salaries paid by the state to hold obligatory large lecture courses. Such explanations are still largely unwelcome even in scholarly discussions of German universities, following the principle of Bacon cited in the first line of Paletschek's book: "We remain silent about ourselves." Mystifications and codes of silence have been professional tools of priestly castes from the beginning of time to the Wizard of Oz. She is also clearer than many of the otherwise excellent approaches reviewed here in recognizing that different traditions and innovations coexisted, for example the "research imperative" and state-funded (and finally, increasingly underfunded) institutes and clinics along with the relatively low-cost and less scholarlyperformance-demanding (as well as socially less exclusive) Catholic theological faculty. She is able to confirm Schmeiser's generalizations about the key role of the Privatdozentur and the plutocratic tendencies in the law and medical faculties, while adding a needed corrective from examining social origins of docents in the other branches of knowledge. Nor does Paletschek ignore the spatial setting and urban pacemaker role of a rapidly-expanding "flagship university" in a distinctly unique German state, Württemberg. Despite the relatively short time-span of this study, nobody can come away from it without a keen sense of the complex dynamism of educational, scientific, and "research" developments rather than a more stereotypical view of measurement by the "Humboldt model." 
If Tübingen was an Aufstiegsuniversität for upwardly mobile faculty, Willett's Erlangen was the only one under review here to be classifiable as the bottom rung of the professorial career ladder. Small, heavily Protestant, and originally built to serve the interests of a regional clientèle (including French Huguenot refugees), the university long recruited teachers more from its own graduates and local professional experts than from what one might call the growing national pool of scholar-scientists. Although little Erlangen, the Protestant service-institution in largely Catholic Bavaria, went along with some of the currents of change in the nineteenth century, various indices from scholarly background and home-towns to connubium suggest strong elements of continuity of the pre-classical type "family university" (Moraw). This social history offers an indispensable rounding-out of the works on large and middle-size universities, which have inevitably attracted the most attention from historians of education, professions, society, and science. Although Willett stops at the threshold of the Nazi regime, he also has some interesting analyses of the differing attitudes toward modernity (and hence politics) among the Weimar and even late-Imperial professorate.

The group of full professors who combined a charismatic self-image, the ideal of a personality-shaping function of scholarship, and faith in the possibility of a holistic-intuitive grasp of truth and essences with a governmental-antipluralist understanding of politics and an organic, unity-centered conception of nation, state, and society continued to represent the majority. $\quad .$. Next to them, particularly in highly specialized and practice-oriented specializations of the medical and philosophical faculties, outsiders began to collect who were indifferent to the ethos of "bearers of culture"... They regarded the disintegrating and socially 
mobilizing effects of the modern mass and machine age ... not as signs of decline but opportunity. (Willett, p. 424)

VII.

Another way to approach university history has wound through

Disziplingeschichte. Asking specialist-professors to write the history of their institutes, seminars, clinics, labs or other subunits is superficially a useful division of labor, although the results have often been unsatisfactory for a more elevated and contextual view of the whole university and its wider social, economic, and cultural-scientific matrix. One of the latest trends in the history of modern academic disciplines is to approach them locally but think of them globally. The volume edited by Horn and Kemnitz is representative of this approach, using the field of pedagogy as it developed in the University of Berlin over nearly two centuries as an interesting disciplinary thread. Although no separate institute for "educational science" was established in Berlin until 1913, reflecting the transition of both the rising educational level and professional status aspirations of teachers, notable professors such as Schleiermacher, Trendelenburg, Paulsen, and Dilthey devoted courses to it before World War I. A dozen contributions deal with such leading figures as well as Eduard Spranger in the Weimar period and developments under Nazi and SED rule. The fact that Pädagogik was, in the words of H.E. Tenorth, an "unwelcome discipline" to most old-line Ordinarien (Horn, p. 191) but insisted on by the state authorities heightens its interest as an areas of tension. The obvious interest by politicians in influencing the training of schoolteachers contrasted with a long-standing resistance by university professors against upgrading the social 
status of the same group by dignifying their training as an academic subject (limited until well into the twentieth century to philological studies for Gymnasium-level teachers). Even when leading lights of pedagogy agreed on the nationalist and state-supporting role of teacher training, as between Eduard Spranger and Nazi-imposed Alfred Bäumler in the 1930s, discriminating readers can see the serious differences within what scholars like Remy conflate as "the German spirit." The successive roles of the University of Berlin in teacher education, under imperial, Weimar, brown, and red aegis makes especially interesting reading.

VIII.

A few concluding remarks about this large array of new and recent books are finally in order. With the inevitable exception of a few individual pieces in conference volumes, all these works are well-written, insightful, meticulously researched, and, where appropriate, deploying sophisticated investigative tools and questions. Except for the contributions meant to be "state of research" reports, they provide a wealth of statistics, documents, and other useful appendix material. Some scholars of my generation, remembering the hardships and frustrations of archival research in the old GDR and the regime's neglect of university archives in particular, may be both grateful for and envious of the wealth of material (not only about East German universities) published here by a new generation of university historians.

One of the assumptions of many of these works (if sometimes only tacitly) is of the importance of the modern German university as a "model" or at least, for a time, a 
distinguished role in scholarly and scientific leadership justifying international attention. Even those questioning the "Humboldt myth" aim at a rescaling of dimensions and a grounding in historical reality of many still-accepted notions of the "rise" and "crisis" of the German higher educational system over two centuries. These revisions and new insights not only inform historians, but (one can hope) also policy-makers keenly aware of the need for change in times when European integration and globalization dominate discussions. It is therefore slightly irritating to note (as in many other areas of historical scholarship emanating from the Federal Republic in recent years) some evidence in these works, too, of decline in attention to relevant scholarship published outside the Germanspeaking world. While most foreign historians publishing essays in volumes reviewed here explicitly and properly refer, for example, to American and other influences on science and educational policy during the twentieth century, some of the German contributions tend to rely almost exclusively on research published in German and/or avoid international comparisons.

At the same time it is heartening to see so much literature newly available that promotes a healthy understanding of the interaction of university and society. With both positive and negative results, as in other developed societies, the era of the university as “ivory tower" buffered from its larger socioeconomic setting and largely left to its autonomous devices seems definitively over, just as its role as conveyor of static knowledge and enculturator of small professional elites has yielded to expectations of mass education and innovative scientific leadership. These works not only describe that transition with wonderful clarity and methodological sophistication, they also attest to new perspectives on the history of knowledge production and dissemination that should 
help deepen our understanding of change and adaptation in one of European civilization's most enduring institutions. 
APPENDIX; WORKS DISCUSSED

Marita Baumgarten, Professoren und Universitäten im 19. Jahrhundert. Zur

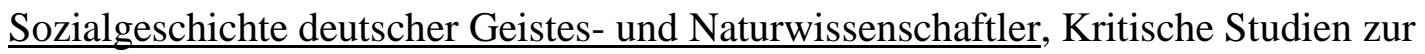
Geschichtswissenschaft, vol. 121 (Göttingen: Vandenhoeck \& Ruprecht, 1997), ISBN 3525-35784-24, pp. 376.; Peter Chroust, Giessener Universität und Faschismus. Studenten und Hochschullehrer 1918-1945, Internationale Hochschulschriften, 2 vols. (Münster/New York: Waxmann, 1994), ISBN 3-89325-200-2, pp. i+515 and ca. 270 [unpaginated]; John Connelly and Michael Grüttner, eds., Zwischen Autonomie und Anpassung: Universitäten in den Diktaturen des 20. Jahrhunderts (Paderborn: Schöningh, 2003), ISBN, 3-506-71941-6, pp. 285; Henrik Eberle, Die Martin-Luther-Universität Halle-Wittenberg in der Zeit des Nationalsozialismus (Halle: Mitteldeutscher Verlag, 2002), ISBN3-89812-150-X, pp. 539; Herbert Gottwald and Matthias Steinbach, eds., Zwischen Wissenschaft und Politik. Studien zur Universität Jena im 20. Jahrhundert (Jena: Bussert \& Stadeler, 2000) ISBN 3-932906-11-X, pp. 208; Notker Hammerstein, Die Deutsche Forschungsgemaeinschaft in der Weimarer Republik und im Dritten Reich. Wissenschaftspolitik in Republik und Diktatur, 1920-1945 (Munich: C. H. Beck, 1999), ISBN 3-406-448267, pp. 382; Klaus-Peter Horn and Heidemarie Kemnitz, eds., Pädagogik unter den Linden: von der Begründung der Berliner Universität im Jahre 1810 bis zum Ende des 20. Jahrhunderts, Pallas Athena, vol. 6 (Stuttgart: Steiner, 2002), ISBN 3-515-08088-0, pp. 313; Raplph Jessen, Akademische Elite und kommunistische Diktatur. Die ostdeutsche Hochschullehrerschaft in der Ulbricht-Āra, Kritische Studien zur Geschichtswissenschaft, vol. 135 (Göttingen: Vandenhoek \& Rupprecht, 1999), 
ISBN 3-525-35797-4, pp. 552; Anne C. Nagel, ed., Die Philipps-Universität im Nationalsozialismus. Dokumente zu ihrer Geschichte, Pallas-Athene, vol. 1 (Stuttgart: Steiner, 2000) ISBN 3-515-07653-0, pp. x + 563; Ilko-Sascha Kowalczuk, Geist im Dienste der Macht. Hochschulpolitik in der SBZ/DDR 1945 bis 1961 (Berlin: Links, 2003), ISBN 3-86153-296-4, pp. 604; Gerhard Müller, Klaus Ries, and Paul Ziche, eds., Die Universität Jena. Zwischen Tradition und Innovation um 1800, Pallas Athene, vol. 2 (Stuttgart: Steiner, 2001), ISBN 3-515-07844-4, pp. 237, DM 88; Sylvia Paletschek, Die permanente Erfindung einer Tradition. Die Universität Tübingen im Kaiserreich und in der Weimarer Republik, Contubernium, vol. 53 (Stuttgart: Steiner, 2001), ISBN 3-51507254-3, pp. xiv+608; Steven P. Remy, The Heidelberg Myth. The Nazification and Denazification of a German University (Cambridge, MA: Harvard University Press, 2002), ISBN 0-674-00933-9, pp. xi+329; Marc Schalenberg, Humboldt auf Reisen? Die $\underline{\text { Rezeption des 'deutschen Universitätsmodells' in den französischen und britischen }}$ Reformdiskursen (1810-1870), Veröffentlichungen der Gesellschaft für Universitäts- und Wissenschaftsgeschichte, vol. 4 (Basel: Schwabe, 2002), ISBN 3-7965-1930-X, pp. 520; Martin Schmeiser, Akademischer Hasard. Das Berufsschiksal der deutschen Universität 1870-1920. Eine verstehend-soziologische Untersuchung (Stuttgart: Klett-Cotta, 1994), ISBN 3-608-91688-1, pp. 436; Reiner C. Schwinges, ed., Humboldt International. Der Export des deutschen Universitätsmodells im 19. und 20. Jahrhundert, Veröffentlichungen der Gesellschaft für Universitäts- und Wissenschaftsgeschichte, vol. 3, (Basel: Schwabe, 2001), ISBN 3-7965-1735-8, pp. x + 503; George Turner, Hochschule zwischen Vorstellung und Wirklichkeit: zur Geschichte der Hochschulreform im letzten Drittel des 20. Jahrhunderts, Abhandlungen zu Bildungsforschung und 
Bildungsrecht, vol. 7 (Berlin: Duncker \& Humblot, 2001), ISBN 3-428-10332-7, pp. 294;

Olaf Willett, Sozialgeschichte Erlanger Professoren, 1783-1933, Kritische Studien zur

Geschichtswissenschaft, vol. 146 (Göttingen: Vandenhoek \& Rupprecht, 2001), ISBN 3-

525-35161-5, pp. 460. These titles by no means exhaust the list of important monographs on the subject appearing since 1989. Exclusions from this review resulted from technical or practical reasons, not judgments of value. Readers of German can also profit greatly from the annual (since 1998) Jahrbuch für Universitätsgeschichte.

\section{ENDNOTES}

Lawrence Stone, "Introduction," The University and Society, 2 vols. (Princeton, 1974-5), I, v.

ii For a more extended discussion of this transformation, see my review of Jessen,

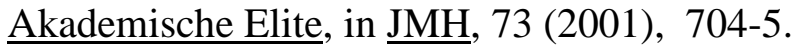

iii Although not included in this review, the recent quinquecentennial celebration edited by H.-J. Rupieper, Beiträge zur Geschichte der Martin-Luther-Universität 15022002 (Halle, 2002), should be mentioned here. Not atypically of the tendency to presentmindedness in such useful works, it devotes over half its attention to the last fifth of the university's existence. That this was still not enough to cover the subject is indicated by the publication of the Eberle volume, under review here, in the same year by the same publisher.

iv In J. Winckelmann, ed., Gesammelte Aufsätze zur Wissenschaftslehre (Tübingen, 1988), pp. 582-613.

Alexander Busch, Geschichte des Privatdozenten (Stuttgart, 1959). 
vi

Ulrike Kohl, Die Präsidenten der Kaiser-Wilhelm-Gesellschaft im

Nationalsozialismus. Max Planck, Carl Bosch und Albert Vögler zwischen Wissenschaft und Macht, Pallas Athena, vol. 6 (Stuttgart, 2002).

vii The phrase appeared in Eisenhower's original draft, but the unflattering reference to Congress was excised from his public address on the urging of staffers.

viii Only later would it become evident that Allied "de-Nazification" policies would prove much less severe and effective than feared by the compromised, and in the American and British cases a pragmatic recognition of the need for the full resumption of professional training overrode initial plans to set high barriers for the rehabilitation of tainted university faculties. See inter alia my "American Reform Efforts: German Professional Education after World War II," in Jürgen Heideking, Mark Depaepe and Jurgen Herbst, eds., Mutual Influences on Education: Germany and the United States in the Twentieth Century, Paedagogica Historica, New Series, vol. 33 (1997), pp. 265-75.

ix There were of course rare birds among the professorate, such as the pacifist Emil J. Gumbel at Heidelberg, about whom see Arthur D. Brenner, Emil J. Gumbel: Weimar German Pacifist and Professor (Leiden, 2001).

x For a suggestive collection first exploring the "myth" as a problem, see Mitchell G. Ash, ed., German Universities, Past and Future: Crisis or Renewal?, Policies and Institutions, vol. 1 (Providence, RI, 1997), and its second edition/translation $\underline{\text { Mythos }}$ Humboldt: Vergangenheit und Zukunft der deutschen Universitäten (Vienna, 1999). 